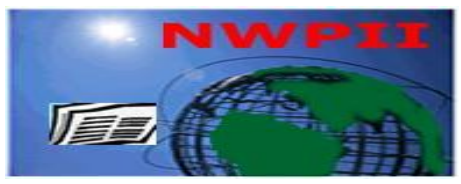

American Journal of Biomedical Sciences

ISSN: 1937-9080

nwpii.com/ajbms

\title{
Bacteria Associated with the Mobile Phones of Medical Personnel
}

\author{
S. E. Amala" and I. F. Ejikema
}

Department of Medical Laboratory Science, Rivers State University of Science and Technology, Nkpolu Oroworukwo, Port Harcourt, Nigeria.

\section{${ }^{+}$Corresponding Author}

Amala, Smart E.

Department of Medical Laboratory Science

Rivers State University of Science and Technology

Nkpolu Oroworukwo

Port Harcourt, Nigeria

E-mail: smart.amala@yahoo.com

Received: 8 January 2015; | Revised: 4 February 2015; | Accepted: 19 March 2015

\begin{abstract}
A total of 300 mobile phones owned and used by medical personnel from University of Port Harcourt Teaching Hospital, Port Harcourt (UPTH) were examined for the presence of bacteria by culture method, 50 mobile phones from non medical personnel were used as control. The collection of samples were carried out by the consents of the mobile phone owners. The percentage prevalence of isolated bacteria on the mobile phones of medical personnel was $80.60 \%$ and the percentage prevalence of bacteria isolated from the mobile phones of non medical personnel was $25.00 \%$. The percentage prevalence of bacteria on the mobile phones of the medical professional groups examined were:- Medical doctors $72.9 \%$., Pharmacists 82\%., Nurses $80 \%$., Medical laboratory scientists $87.50 \%$, Medical Record personnel $80 \%$ respectively. The overall percentage occurrences of isolated bacteria from phones of medical personnel were: Coagulase negative Staphylococci 35.3\%., Staphylococcus aureus 20.7\%., Streptococcus spp. 14.3\%., Pseudomonas aeruginosa 6.0\%., and E. coli $4.3 \%$ respectively. For the non medical personnel; Coagulase negative Staphylococci 20\%, Staphylococcus aureus 10\%; Streptococcus spp. 10\%, Pseudomonas $6.0 \%$ and E. coli $4.0 \%$ respectively. Decontamination of 50 mobile phones that showed heavy growth with $70 \%$ isopropyl alcohol rendered the phones bacteria free on repeat culture. The percentage prevalence rate of bacteria on mobile phones by gender revealed that the mobile phones of the males haboured more bacteria $88.6 \%$ than those of their females counterparts $72.6 \%$ for health personnel; whereas the non medical personnel, males had $32.0 \%$ and females $18.8 \%$. The presence of bacteria associated with human infections on mobile phones of medical personnel may suggest that they serve as medium of transmitting these hospital acquired bacteria.
\end{abstract}

Key Words: Bacteria; associated; mobile phones; medical personnel 


\section{Introduction}

Mobile phones, like other inanimate objects can harbour microorganisms associated with human infections. Human hands usually harbour microorganisms as part of normal microflora, as well as transient microbes acquired from the environment (Lindberg et al., 2004). It is conceivable that the transfer of pathogenic bacteria could occur between human hands and mobile phones (Kurumaningrum et al., 2003).

Various researchers have studied the survival of bacteria on the surface of inanimate objects such as stainless steels, plastic and computer keyboards subsequent to contamination; most of these studies had shown that these surfaces are relatively non-toxic to bacteria. They concluded by stressing the potential roles that inanimate objects could play in harbouring and transmitting pathogenic microbes (Oil et al., 2003; Rusin et al., 2002). Mobile phones act as good habitat for microorganisms to thrive, especially in humid and warm environment; for medical personnel, it may serve as a vehicle of transmitting even nosocomial infections. The number of persons using the same mobile phones and the personal hygiene of the individuals may also play key roles in transmission of microbes (Brady et al., 2007). Findings have shown that about one-fifth of cellular phones examined were found to habour pathogenic bacteria, testifying that these devices may serve as vehicles of transmission (Goldblatt et al., (2007). In this study, the aim is to isolate, identify the bacteria carried on the mobile phones of medical personnel and determine their percentage occurrences.

\section{Material and Methods}

\section{Study Area}

The study area chosen was University of Port Harcourt Teaching Hospital, (UPTH) Port Harcourt, Nigeria; this was to enable us obtain the required number of samples from volunteers medical personnel.

\section{Media Preparation and Isolation of Bacteria}

Nutrient agar and MacConkey agar powder were reconstituted and sterilized according to the manufacturer's instruction. The molten agar were allowed to coal to about $47^{\circ} \mathrm{C}$ and poured onto sterile plastic petri-dishes. They were allowed set and stored in the refrigerator for subsequent uses. Sample was collected from the anterior and posterior of each mobile phone with a sterile swab stick. The samples were inoculated onto agar plates and streaked out with sterile wire-loop. These were incubated aerobically at $37^{0} \mathrm{C}$ for $18-24$ hours and examined for growth. A total of 50 mobile phones that showed heavy growth were cleaned with $70 \%$ isopropyl alcohol and repeat culture samples were collected, cultured after 10 minutes.

\section{Identification of Isolates}

The plates that had growth were selected for identification of isolated bacteria. The identification of isolated bacteria were done by examination of cultural characteristics, morphological characteristics, Gram reaction, chemical and biochemical tests according to (Cheesbrough, 2002., Criuckshank et al., 2006).

\section{Quality control and Statistical Analysis}

Each batch of sterile swab sticks was inoculated onto nutrient agar plates and each batch of already prepared agar plates were incubated overnight to check sterility. Data obtained from this study were subjected to statistical analysis using statistical package for social sciences (SPSS) version 20.

\section{Results}

A total of 350 mobile phones were examined for the presence of bacteria, 300 were owned and used by medical personnel, whereas 50 were owned and used by non-medical personnel. Out of the 300 examined 242 had growth with an overall percentage prevalence rate of $(80.6 \%)$. Out of the 50 non-medical personnel $25(50 \%)$ had growth. The percentage prevalence rates observed among the medical professional groups were: medical laboratory scientists, 80 examined, $70(26.6 \%)$ had growth, medical doctors 70 
sampled 51(17.0\%), pharmacists 50 examined $41(13.6 \%)$ had growth respectively. Nurses 50 analyzed, 40(13.3\%) and medical record personnel 50 sampled $40(13.3 \%)$ had growth respectively. The medical laboratory scientists had high percentage prevalence rate among the medical professional groups as shown in table 1.

Table 1. Percentage prevalence of bacteria isolated from the mobile of medical and paramedical personnel.

\begin{tabular}{|l|c|l|}
\hline Subjects & Number Sampled & Number Positive \\
\hline Medical lab. Scientist & 80 & $70(26.6)$ \\
\hline Doctors & 70 & $51(17.0)$ \\
\hline Pharmacists & 50 & $41(13.6)$ \\
\hline Nurses & 50 & $4013.3)$ \\
\hline Medical record personnel & 50 & $40(13.3)$ \\
\hline Total(Medical personnel) & 300 & $242(80.6)$ \\
\hline $\begin{array}{l}\text { Non-medical personnel's } \\
\text { (control group) }\end{array}$ & 50 & $25(50)$ \\
\hline
\end{tabular}

Numbers in parenthesis $=$ percentages

Table 2. Percentage prevalence of bacteria isolated from the mobile phones of medical and non medical personnel by gender.

\begin{tabular}{|l|l|l|l|l|}
\hline \multirow{2}{*}{$\begin{array}{l}\text { Medical professional } \\
\text { groups }\end{array}$} & \multicolumn{2}{|c|}{ Male } & \multicolumn{2}{c|}{ Female } \\
\cline { 2 - 5 } & $\begin{array}{l}\text { Number } \\
\text { Sampled }\end{array}$ & $\begin{array}{l}\text { Number } \\
\text { Positive }\end{array}$ & $\begin{array}{l}\text { Number } \\
\text { sampled }\end{array}$ & $\begin{array}{l}\text { Number } \\
\text { Positive }\end{array}$ \\
\hline Med. Lab. Scientist & 49 & $47(15.6)$ & 31 & $23(7.6)$ \\
\hline Doctors & 38 & $31(10.3)$ & 32 & $20(6.6)$ \\
\hline Pharmacists & 33 & $30(10.0)$ & 17 & $11(3.6)$ \\
\hline Nurses & 00 & $0(0.00)$ & 50 & $40(13.3)$ \\
\hline Medical records & 30 & $25(8.3)$ & 20 & $15(5.0)$ \\
\hline Total (Medical personnel) & 150 & $133(44.3)$ & 150 & $109(36.3)$ \\
\hline Non-medical personnel & 28 & $16(32.0)$ & 22 & $9(18.8)$ \\
\hline
\end{tabular}

Numbers in parenthesis $=$ percentages

The percentage prevalence rate of isolated bacteria from the mobile phones of medical personnel by gender were: Medical laboratory scientists, males $15.6 \%$, females, $7.6 \%$; doctors, males, $10.3 \%$, females, $6.6 \%$; pharmacists, males, $10.0 \%$, females $3.6 \%$; nurses, males, $0.00 \%$, females $13,3 \%$; medical record personnel, males, $8.3 \%$, females, $5.0 \%$ respectively. The non- medical personnel, males $32.0 \%$ and female $18.0 \%$. The overall prevalence rates of isolated bacteria from males was $44.3 \%$ and females was $36.3 \%$ respectively as shown on table 2 .
The percentage occurrences of isolated bacteria from the mobile phones of medical personnel were: Coagulase negative Staphylococci 43.8\%, Staphylococcus aureus $25.6 \%$, Streptococci 17.7\%, Pseudomonas $7.4 \%$ and E. coli $5.3 \%$ respectively; while the percentage occurrences of bacteria isolated from the mobile phones of non medical personnel were: Coagulase negative Staphylococci $40.0 \%$, Staphylococcus aureus $20.0 \%$, Streptococci $20.0 \%$, Pseudomonas $12.0 \%$ and E. coli $8.0 \%$ respectively. The percentage occurrences of 
isolated bacteria from the mobile phones of the medical personnel by professional groups showed that medical laboratory scientists had high percentage occurrences of isolated bacteria compared to other professional groups and the percentage occurrences by medical personnel were as shown in table 3.

Table 3. Percentage occurrences of bacteria isolates from medical and non-medical personnel.

\begin{tabular}{|l|l|l|l|l|l|l|l|}
\hline $\begin{array}{l}\text { Bacteria } \\
\text { isolated }\end{array}$ & $\begin{array}{l}\text { Medical } \\
\text { lab. } \\
\text { scientist }\end{array}$ & $\begin{array}{l}\text { Medical } \\
\text { doctors }\end{array}$ & Nurses & Pharmacists & $\begin{array}{l}\text { Medical } \\
\text { records }\end{array}$ & $\begin{array}{l}\text { Total } \\
\text { medical } \\
\text { personnel }\end{array}$ & $\begin{array}{l}\text { Non medical } \\
\text { personnel }\end{array}$ \\
\hline $\begin{array}{l}\text { Coagulase }-v e \\
\text { Staphylococci }\end{array}$ & $30(12.3)$ & $25(10.3)$ & $16(40.0)$ & $20(8.2)$ & $15(6.2)$ & $106(35.3)$ & $10(40.0)$ \\
\hline $\begin{array}{l}\text { Staphylococcus } \\
\text { aureus }\end{array}$ & $17(7.0)$ & $15(6.2)$ & $10(4.2)$ & $10(4.2)$ & $10(4.2)$ & $62(20.7)$ & $5(20.0)$ \\
\hline Streptococci & $10(4.2)$ & $10(4,2)$ & $7(2.8)$ & $8(3.3)$ & $8(3.3)$ & $43(14.3)$ & $5(20.0)$ \\
\hline Pseudomonas & $5(2.1)$ & $1(0.4)$ & $5(2.1)$ & $2(0.8)$ & $5(2.1)$ & $18(6.0)$ & $3(12.0)$ \\
\hline Escherichia coli & $8(3.3)$ & $0(0.00)$ & $2(0.8)$ & $1(0.4)$ & $2(0.8)$ & $13(4.3)$ & $2(8.0)$ \\
\hline Total & $70(28.9)$ & $51(21.0)$ & $40(16.5)$ & $41(16,9)$ & $40(16.5)$ & $242(80.6)$ & $25(50.0)$ \\
\hline
\end{tabular}

Numbers in parenthesis $=$ percentages

\section{Discussions}

Mobile phones are indispensable tools of communication, both at home and at work, they are always picked, dropped or pocketed, therefore has the potential of acquiring microbes from the handlers and the environment. Mobile phones as inanimate objects had been shown to posses the potential for the survival of microorganisms, some bacteria can survive for months, viruses such as corona, coxackie and influenza can persist for few days; and herpes virus can persist for a week (Kramer, et al., 2006).

The high rate of bacterial colonization of mobile phones of medical personnel suggest their regular exposure to the bacteria in the hospital environment, possibly transmitted in course of carrying out their professional duties. Contact with surfaces, patients, infected materials, and the individual's level of personal hygiene may influence the rate of colonization. Research had shown that about $69 \%$ of mobile phones of medical personnel are contaminated with microorganisms (Borer et al., 2005).

Increased colonization of mobile phones by bacteria had been associated with hospital environments. It was also noted that the mobile phones of medical personnel are colonized by bacteria that carry drug resistant genes which could be inimical to critically ill patients (Brady et al., 2006; Goldblatt et al., 2007).

The percentage prevalence of bacteria on the mobile phones of medical personnel was $(80.6 \%)$ compared with those of non-medical personnel $(50.0 \%)$ which clearly explains the difference in the rates of contamination or colonization and risks associated with the medical professions. Statistical analysis $\mathrm{P}<0.05$ showed significant difference between the rates of bacteria colonization of the mobile phones of medical personnel and non medical personnel. Among the professions, the medical laboratory scientists had a prevalence rate of $(87.50 \%)$, this high prevalence might be because they deal more directly with infected specimens, the aerosols 
created in laboratories and the contact of their mobile phones with the laboratory benches might account for the slightly high prevalence rate. Calls and answers to call while working are obvious enabling transfer of microbes. The pharmacists do not deal with infected specimens directly but prescription forms from the wards and out-patient clinics carried by patients, nurses or patient relations are vehicles of transmitting microbes. The counter where exchanges of prescription forms and drugs occur might be a medium of transferring microbes. Prescription forms in patient folders and laboratory result sheets may carry microbes from wards and laboratories areas for onward transmission. Most pharmacists dispense drugs without hand gloves and the handling of prescription forms or patient folder with bare hands may aid adherence and subsequent transfer to mobile phones. The medical doctors consulting rooms are generally, the tables are occupied by those on shift for each day. Several persons making use of particular table means that several indigenous microbiota had been deposited on it for transmission. The patient folder are read through by physicians to know patient's history, the previous prescription forms and laboratory results; may aid adherence of microbes to the palms for onward transmission to mobile phones. Even the stethoscope and sphygmomanometer used by doctors and or nurses could mediate transfer of microbes. Statistical analysis at $\mathrm{P}<0.05$ did not show significant difference between bacteria colonization among the professional groups. Some of these processes that mediate transmission are applicable also to medical record personnel.

Most women keep their mobile phones in their purses or hand bags protected from contaminants. Contamination of surfaces such as mobile phones etc, are by exposure and contact with possible contaminants. The possibility of the mobile phones of the male counterparts (in the same profession) habouring more bacteria are likely because the males always hold mobile phones in their palms, pocked or kept on tables or other surfaces from which they may acquire additional microbes. Although, statistical analysis $\mathrm{P}<0.05$ did not show significant difference between the carriage rates of males and females mobile phones.

The use of $70 \%$ isopropyl alcohol for decontamination was suggested by (Rutala, 1996). The decontamination of 50 mobile phones which showed heavy growths of bacteria when initially cultured were wiped with $70 \%$ isopropyl alcohol, and samples for repeat cultures taken after 10 minutes interval yielded no growth. The suggestion of the development of effective preventive strategies that will include environmental decontamination, hand hygiene, surveillance and contact isolation for the prevention of nosocomial infections may be implemented; but the restriction of mobile phones in intensive care units and isolation ward are ineffective in the spread of infections (Neely and Singh, 2002).

The results of percentage occurrences of isolated bacteria in this study revealed Staphylococci spp. as the most prevalent bacteria. This results are similar to that obtained by (Runslimanungrum et. al., 2003; Lindberg et al., 2004), both reported high percentage occurrences of Staphylococci on computer keyboards and other surfaces. Coagulase negative Staphylococci and Staphylococcus aureus are normal flora of human, carried on hands, nose, mouth, skin, cloths, bed linen and other human environments (Melnick and Edward, 2004). Staphylococci occur in about 30 to $50 \%$ in humans and about $25 \%$ on the skin and nostril of healthy humans and animals. The major route of Staphylococci transfer onto mobile phones was the palms as also observed by (Hui et al., 2001). This accounts for the predominance prevalence of Staphylococci spp. on mobile phones. A serious implication of the predominance of Staphylococci is that both coagulase negative Staphylococci and Staphylococcus aureus are implicated in divers infections. Mobile phones may serve as major vehicle of harbouring and transmitting Staphylococci associated with infections.

Gram positive cocci such as Streptococcus pyogenes, Staphylococci and Enterococcus had been shown to survive for months on dry surfaces; this also may account for their presence, although, the presence of Enterococcus might indicate faecal contamination. The isolation of 
the recalcitrant bacteria, Pseudomonas which had defiled the activities of many antiseptic and germicides used in disinfecting hospitals was of concern and public health interest. Pseudomonas is metabolically versatile, ubiquitous in both terrestrial and aquatic environs (Ramos, 2004). Findings have shown that Pseudomonas is very recalcitrant to manage in infections (Marc et al., 2001). The presence of this organism on mobile phones of medical personnel calls for serious public health attention.

E. coli is the most prevalent aerobic bacteria in human/animal faeces, its presence suggests faecal contamination. Poor personal hygiene or contamination from already contaminated site may account for the presence of this organism. Infections by $E$ coli ranges from gastro-entritis, UTI, wound infections etc the presence of E.coli is a direct indicator that other Enterobacteriaecae could be carried on mobile phones as also noted (Karabay et al., 2007 and Tambekar et al., 2008.

\section{Conclusion}

Mobile phone as inanimate objects remains a known vehicle transmitting infectious agents, especially mobile phones of medical personnel as a result of their interactions with the hospital environments. Mobiles phones of medical personnel should be decontaminated intermittently to rid off the bacterial contents.

\section{References}

1. Brady, R. R., Wasson, A., Stirling, I. McAlister \& Damani, N. N. (2006). The incidence of bacteria known to cause nosocomial infection on health care workers mobile phone. Journal of Hospital Infection. 62, $123 \quad-\quad 125 . \quad$ DOI: 10.1016/j.jhin.2005.05.005

2. Cheesbough, M. (2002).District laboratory practice in tropical countries, part 2 . Cambridge University Press, Madrid, Spain.

3. Criuckshank, R., Duguid, J.P., Marmion, d. p., \& Swain, P. (2006). Medical microbiology $12^{\text {th }}$ edition, Churchhill L Iivingstone,

Edinburgh.

4. Ekrakene, T., \& Igeleke, C. L. (2007). Microorganisms associated with public mobile phones along Benin-Sapele express way, Benin city, Edo-State of Nigeria. Journal of Applied Science 3, 2009 - 2012.

5. Goldblatt, J. G., Krief, I., klonsky, T., Haller, D., Millon, V., Sixsmith, M. D., Srugo, I. \& Potasman, I. (2007). Use of cellular telephones and transmission of pathogens by medical staff in New York and Israel. Infection Control and Hospital Epedemiology 28,500-502. DOI: 10.1086/513446

6. Karabay, O.; Kocoglu E. \& Tahtaci M.(2007). The role of mobile phone in the spreed of bacteria associated with nosocomial infection. Journal of Infection in Developing Countries 1, 72-73.

7. Kramer, A., Schwebike, I. \& Kampf, G. (2006). The length of pathogens survival on inanimate objects. A systematic review. British medical council on infectious diseases 6,130.

8. Kusumrungum, H. D., Riboldi, G., Hazelogen, W. C. \& Beumer, R. R. (2003). Survival of food borne pathogens on stainless steel surfaces and cross contamination to foods. International Journal of Food Microbiology, $55,277-236$.

9. Linberg, E., Adlerberth, Hesselmar, B., \& Wold, A. (2004). High rate of transfer of staphylococcus aureus from patient skin to infant gut flora. Journal of Clinical Microbiology. 42, 530 - 534. DOI: 10.1128/JCM.42.2.530-534.2004

10. Marc, F., Kathleen, J., Susan, W., Phyllis, P. L., Stephamie, F., David, R. \& Lisa, S. (2000). Edemic Pseudomonas aeruginosa infection in neonatal intensive care unit. Journal of Clinical Microbiology, 43, 1198 1204.

11. Melinck, J. \& Edward, A. (2004). Medical Microbiology. New York, Mc Gramhill professional. U.S.A.

12. Neely, A. N. \& Stitting, D. F. (2002). Basic microbiologic and infection control information to reduce the potential 
transmission of pathogens to patients via computer hardware. Journal of American Information Association, 9, 500 - 508. DOI: 10.1197/jamia.M1082

13. Oie, S., Hosokawa, I. \& Kamiya, A. (2002).Contamination of room handles by methicillin sensitive/methicillin resistance Staphylococcus aureus. Journal Hospital Infection 51,140-143. DOI: 10.1053/jhin.2002.1221

14. Ramos, j. L. (2004). Pseudomonas, New York, Kfuwer Academic Plenum publisher. U. S. A.

15. Rutala, W. A. \& APIC Guideline committee (1996). APIC guideline for the selection and use of disinfectants. American Journal of infection control, 24, 313 - 342. DOI: 10.1016/S0196-6553(96)90066-8

16. Rusin, P., Maxwell S. \& Gerba J.C. (2002). Comparative surface to hand and fingertip to mouth transfer of Gram positive and Gramnegative bacteria and phage. Journal of Applied Microbiology. 9,585-592. DOI: $\underline{\text { 10.1046/j.1365-2672.2002.01734.x }}$

17. Tambekar,D.H.; Gulhane, SP.B.; Dahikar, S.G. \& Dudhane M.N.(2008). Nosocomial hazard of doctor's mobile phones in hospitals. Journal of Medical Science, 8,7376. DOI: $\underline{10.3923 / \mathrm{jms} .2008 .73 .76}$ 